\title{
THE EFFECTS OF SCHOOL DESEGREGATION UPON STUDENTS' RACIAL ATTITUDES AND BEHAVIOR: A CRITICAL REVIEW OF THE LITERATURE AND A PROLEGOMENON TO FUTURE RESEARCH*
}

\author{
John B. McConahay $\dagger$
}

\section{INTRODUCTION}

The purpose of this article is two-fold: first, to review critically the existing literature on the effects of school desegregation upon race relations and attitudes of students; and second, to discuss the critical issues that should influence future research in this area. Hence, as its title indicates, this article is both a review and a prolegomenon-a critical discussion serving to set the stage for future research.

We might begin with the rhetorical question, How is the study of race relations important to desegregation research and policymaking? The rhetorical answers that race relations are what school desegregation is all about, and that we need no further justification for studying them could follow. However, beyond this, the study of race relations within schools is important because of the potential impact they have upon the racial climate of the larger community and the nation and because of their effects on student academic achievement. ${ }^{1}$ Harmonious race relations should not be regarded as the most important goal of school desegregation, however. Amicable relations among racial and ethnic groups can exist alongside grossly unjust inequalities of opportunities and outcomes. Ceteris paribus, harmonious race relations and unprejudiced attitudes might be worthy goals-but only if other things are equal, or nearly so.

\footnotetext{
* Research support for this article was provided by the National Review Panel on School Desegregation Research through grants from the Ford Foundation, the National Institute of Education, and Duke University. Research assistance was provided by Wendy Robineau and Jack W. Bonner, IV.

$\dagger$ Associate Professor of Policy Sciences and Psychology; Associate Director of the Institute of Policy Sciences and Public Affairs, Duke University.

1. Katz, The Socialization of Academic Motivation in Minority Group Children, in Nebraska SymPosium on Motivation 1967, at 133 (D. Levine ed. 1967); Lewis \& St. John, Contribution of CrossRacial Friendship to Minority Group Achievement in Desegregated Classrooms, 37 SOCIOMETRY 79 (1974).
} 


\section{Previous Literature Reviews}

Three major reviews of the social science studies of the effects of school desegregation on student attitudes and behavior were published as of June, 1978. Carithers ${ }^{2}$ reviewed the literature up to 1970, and Cohen $^{3}$ and St. $\mathrm{John}^{4}$ surveyed the literature through 1974. One other major review, by Amir, ${ }^{5}$ touched upon the school desegregation research as part of a broader review of research bearing on the "contact hypothesis."6 Amir's work is analyzed in a subsequent section of this article, as part of a discussion of the hypothesis that the nature of the interracial contact determines its effect upon racial attitudes.

\section{A. Definitions}

It is important to define at the outset the terms "school desegregation" and "race relations," as used in this article, since previous reviews have not always been precise in defining or applying the two terms, which accounts for some of the confusion about the relationship between the two. My definition of school desegregation draws upon the commonly accepted meaning of the term. ${ }^{7}$ School desegregation involves the transformation of a school, classroom, or school system from a state in which the races were separated or segregated to a state in which they attend schools or classes, or both, in more than token numbers. Thus, there are three important components of the term: (1) reunion or unseparation and (2) race mixing (3) in schools.

By the term race relations I mean the attitudes and behaviors of blacks (and in a few cases, other minorities) vis à vis whites, and the attitudes and behaviors of whites vis à vis blacks (and other minorities) within the school setting. An attitude is an internal psychological state that usually can be inferred from written or verbal behavior. By contrast, behavior involves overt physical acts that can be observed directly. The relationship between the two has been

2. Carithers, School Desegregation and Racial Cleavage, 1954-1970: A Review of the Literature, 26 J. Soc. Issues, Autumn 1970, at 25.

3. Cohen, The Effects of Desegregation on Race Relations, 39 LAw \& Contemp. Prob., Spring 1975 , at 271 .

4. N. St. John, School Desegregation: Outcomes for Children 64 (1975).

5. Amir, The Role of Intergroup Contact in Change of Prejudice and Ethnic Relations, in TowARDs THE Elimination of Racism 245 (P. Katz ed. 1976).

6. The "contact hypothesis," discussed in notes $111-117$ infra and accompanying text, was first elaborated by Gordon Allport in 1954. See generally G. Allport. The Nature of Prejudice 261 (1954).

7. The Oxford English Dictionary's definition is "To reunite (persons, classes, races, etc.) hitherto segregated; esp. (orig. U.S.) to abolish racial segregation in schools and other institutions. So desegreg ation, such reunion or abolition." I A Supplement to The Oxford English DictionARY A-G 799 (R. Burchfield ed. 1972). 
the subject of many scholarly debates over the years. ${ }^{8}$ As Oskamp indicated, most social scientists view specific behaviors as a joint function of prior inclinations (attitudes) and the stimuli of the immediate situation. ${ }^{9}$ Hence, knowing a person's attitudes toward a given minority group should help to predict how the person will act toward or interact with members of that minority group. Predicting behavior from attitudes, however, might be very wrong in some cases, because the demands of the immediate situation can outweigh attitudes. For example, someone might dislike bigots, think they are evil, and express the intention of criticizing them to their faces-and then behave quite timidly in the presence of the next bigot he or she meets if the bigot stands six and a half feet.tall and weighs over 250 pounds.

In the short run, we might be happy if people behave nicely toward one another regardless of their attitudes. But in the long run, it will be a great deal less costly and anxiety arousing if students, teachers, and people in general have positive attitudes toward one another as well. Therefore, it is worth examining both attitudes and behavior in the context of school desegregation.

\section{B. Previous Reviews}

Though the preceding definitions may appear excessively simple and pedantic, they are not trivial; the three reviews of the literature prior to this one include a great many studies that would be excluded by a consistent adherence to these definitions.

First, not all of the studies cited in the reviews are in school settings. For example, St. John includes in her review a study by Yarrow, Campbell, and Yarrow, ${ }^{10}$ which was done in a summer camp, using volunteer subjects of school age. Another example is the study by Deutschberger, ${ }^{11}$ cited by both Carithers and St. John, which, though it involved a nonrandom sample of school age youngsters living in neighborhoods either undergoing racial change or not having this experience, focused on the neighborhood and not the schools. Some of the youngsters in both types of neighborhoods were old enough to have dropped out of school; some in the desegregating neighborhoods were attending segregated private or parochial schools, and some in the segregated neighborhoods were attending desegregated schools.

Second, the previous reviewers, especially St. John, included studies of children undertaken without regard to whether they were experiencing

8. LaPiere, Attitudes vs. Actions, 13 Soc. Forces 230 (1934); McGuire, The Nature of Attitudes and Attitude Change, in 3 The Handbook of Social Psychology 136, 140-71 (2d ed. G. Lindzey \& E. Aronson 1969); S. Oskamp, Attitudes and Opinions 10 (1977).

9. S. Oskamp, supra note 8, at 11 .

10. Yarrow, Campbell, \& Yarrow, Acquisition of New Norms: A Study of Racial Desegregation, 14 J. Soc. Issues, Winter 1958 , at 8.

11. Deutschberger, Interaction Patterns in Changing Neighborhoods: New York and Pittsburgh, 9 SOCIOMETRY 303 (1946). 
desegregation. In her list of twenty-two studies of the effects of school desegregation upon attitudes, St. John included thirteen that were crosssectional (for which the data are from only one point in time). Fourteen of her nineteen studies of interracial behavior were cross-sectional. Thus, there was no explicit time dimension in most of the studies of $d e$-segregation she reviewed. Furthermore, many of the cross-sectional studies did not even have segregated schools to compare with desegregated schools: they merely compared different black-to-white ratios in previously desegregated schools. ${ }^{12}$

The previous reviews had another common tendency. They were unanimous in deploring the low methodological quality of most of the studies yet made little distinction between sound and hopelessly flawed studies. Is it any wonder, then, that these reviews were also unanimous in concluding that the studies showed great inconsistencies in their outcomes? The reviewers found that some studies showed that desegregation produced an increase in tolerance and interracial friendships, some studies showed a decrease, and some studies showed no effects from desegregation.

\section{REVIEW OF THE LITERATURE}

\section{A. Procedure}

With a few exceptions, this analysis of the literature is limited to published studies. ${ }^{13}$ Most of the published studies were methodologically worthless; the unpublished studies were (with some noted exceptions) unpublished because they indeed deserved that fate. Only one study published before 1960 is reviewed: aside from their poor methodological quality, studies published before 1960 were made in an era of the school desegregation controversy that was quite different from the present one. ${ }^{14}$

Finally, I have distinguished the methodologically sound studies from

12. One study, conducted by Koslin, Koslin, Pargament, and Waxman, was cited by St. John as a study of "school desegregation" but was actually a study of "racial balance" in classrooms. A classroom was balanced in this study if its black/white ratio approximated the black/white ratio for the school as whole. Hence, a $100 \%$ white classroom in a $100 \%$ white school was as "balanced" as a $50 \%$ white classroom in a $50 \%$ white school. Obviously, the two are hardly equally desegregated. See Koslin, Koslin, Pargament, \& Waxman, Classroom Racial Balance and Students' Interracial Attitudes, 45 Soc. Educ. 386 (1972).

13. In order to canvass the literature as thoroughly as possible, all related books, periodicals, and documents available in the libraries of Duke University and the University of North Carolina were reviewed. I also attempted to obtain all of the materials, including unpublished materials, included in the previous reviews, although I was not completely successful in this effort. Finally, a search of the Educational Resources Information Center (ERIC) document series for relevant unpublished materials was conducted. Given the large quality gap between the published and unpublished studies, I am reasonably confident that no significant study was excluded in the gathering of materials for this review.

14. McConahay \& Hough, Symbolic Racism, 32 J. Soc. Issues, Spring 1976, at 23, 39-44. 
those that were so flawed as to be uninterpretable. In making this distinction, I have not been rigid. Studies I did not consider methodologically valid for drawing conclusions about interracial attitudes were nevertheless reviewed in detail for any light they could shed upon interracial behaviors because of the different methodological requirements associated with these two aspects of race relations. Furthermore, I have reviewed the cross-sectional or correlational studies, which furnish the weakest methodological designs for studying attitudes and behaviors, as well as the experimental, quasi-experimental, and longitudinal studies. The cross-sectional studies can supplement the more rigorous ones and thus help us decide among alternative policies to promote better race relations in already desegregated schools.

\section{B. Experimental and Quasi-Experimental Studies}

\section{Methodological Considerations}

In order to evaluate the effects of an educational or some other social change with any scientific confidence, a minimal level of methodological rigor is required. Though there is disagreement about many aspects of social science, there is a reasonable consensus about what these minimal methodological requirements are. ${ }^{15}$ First, there should be a pretest. For example, racial attitudes should be measured before desegregation takes place. Second, there should be a posttest. Racial attitudes should be tested at least once after desegregation takes place. The two tests must use the same measuring instrument. ${ }^{16}$

Of equal importance to a pretest and posttest is a comparison group. In a true experiment, where there is random assignment of the subjects of the study to the desegregated or segregated condition, the comparison group becomes a control group statistically identical to the treated group in every way, except in that it did not receive the desegregation treatment. Where random assignment is not possible, the comparison group should be made as equal to the treatment group as possible through matching or statistical controls. ${ }^{17}$

15. Campbell, Reforms as Experiments, 24 Am. Psychologist 409 (1969); D. Campbell \& J. Stanley, Experimental and Quasi-Experimental Designs for Research (1966); McConahay, Experimental Research, in Handbook of Political Psychology 356, 370 (J. Knutson ed. 1973) [hereinafter cited as McConahay, Experimental Research]; D. NaCHMIas \& C. NaChmias, ReSEARCH Methods in the Social Sciences 29 (1976).

16. One of the studies cited in Cohen, supra note 3 , at 284, is Bullock \& Braxton, The Coming of School Desegregation: A Before and After Study of Black and White Student Perceptions, 54 Soc. ScI. Q. 132 (1973). This study is methodologically poor for a number of reasons, but perhaps its worst flaw is that the questions asked before desegregation were totally different from the questions asked after desegregation. There is no way to determine whether changes in the percentage taking a prosegregation position are due to the desegregation experience or to the changes in the wording and format of the questions.

17. The usual procedure is analysis of covariance or multiple regression. See J. CohEN \& P. Cohen, Applied Multiple Regression/Correlation Analysis for the Behavioral Sciences (1975). 
In order to analyze the effects of desegregation on almost anything, all four combinations of testing and comparison should be present in the design: a pretest and posttest on the desegregated students and a pretest and posttest on the segregated comparison group. For example, if the pretests are absent (as in all cross-sectional or correlational studies), the differences in attitudes between segregated and desegregated students may have been bigger, smaller, or the same before the desegregation took place as afterward. Or, to choose another example, if students become less prejudiced after desegregation, this might have happened because they matured (grew older) during the period of the study, because everyone in the country became less prejudiced during the period, ${ }^{18}$ or because the students-having taken a prejudice test one time-were able to fake being less prejudiced the second time the test was administered. ${ }^{19}$ Without a comparison group that undergoes both a pretest and a posttest, there is no way of knowing which of these potential causes produced the effect. Finally, the students must be assigned randomly ${ }^{20}$ to the segregated or desegregated situations for a true experiment. My search of the literature did not turn up a single true experiment. ${ }^{21}$

When students cannot be randomly assigned, but the researchers or evaluators can find reasonable ways to compensate for the lack of random assignment, the study is called a quasi experiment. My search of the literature turned up only two published studies that even approximated the require-

18. See Taylor, Sheatsley, \& Greeley, Attitudes Toward Racial Integration, 238 Scientific Am., June 1978 , at 42 .

19. See Sigall \& Page, Current Stereotypes: A Little Fading, A Little Faking, 18 J. Personality \& Soc. Psych. 247 (1971); McConahay, Hardee, \& Batts, Race of Experimenter and Prejudice Scores (1978) (unpublished paper, Duke University).

20. To meet the requirements for random assignment, students must not be able to choose which school or classroom they will attend; and the assignments must be made by a chance mechanism by which a student is as likely to be in the segregated situation as in the desegregated situation. See Campbell \& Stanley, supra note 15, at 14; McConahay, Experimental Research, supra note 15 , at 369 .

21. There is an important study by Robert Crain, working with the National Opinion Research Center of the University of Chicago, that examines the effects of the use of Emergency School Assistance Program (ESAP) funds in Southern schools. Though it incorporated a true experimental design, I have not reviewed it here because it was not a study of desegregation per se. All of the 39 experimental high schools, 39 control high schools, 68 experimental elementary schools, and 68 control elementary schools included in this study were desegregated or desegregating. The difference between experimental and control schools was simply that the experimental group of schools received ESAP funds, while the control schools did not. Overall. there was not an effect for the experimental manipulation upon attitudes toward integration. That is, experimental and control students did not differ on scales designed to measure this attitude. There were some programs in the experimental (ESAP-funded) schools that may have made students more favorable to integration, and some programs in the experimental schools that may have made them less favorable. However, there is no way to untangle these effects within the framework of experimental logic. See R. Crain, 1 Southern Schools: An Evaluation of the Effects of the Emergency School Assistance Program and of School Desegregation 42-92 (National Opinion Research Center Report No. 124 A, 1973) (ERIC Document No. 085 426). 
ments for a quasi experiment. Both of these studies have major weaknesses, but they are discussed here because they were included in the reviews by Cohen and St. John.

\section{The Studies}

The first of the two quasi experiments was published by Webster in $1961 .^{22} \mathrm{He}$ pretested the social acceptance attitudes of both black and white students in June, 1959, while they were attending either an all-white or an allblack elementary school in a school district in the San Francisco Bay area. He then retested those attitudes in March, 1960, following desegregation, using the same social distance scale. Also in March of 1960, he administered his social distance scales to samples of whites and blacks who were attending allwhite or all-black junior high schools in two nearby cities in the San Francisco Bay area. This study concluded that whites' social acceptance of blacks declined as a result of desegregation, while blacks' social acceptance of whites increased ${ }^{23}$ However, since the comparison students were tested only one time and attended schools in a different school system, the study's results are of little value in any objective sense. The changes in attitudes may have been due to the transition from elementary school to junior high, or to external historical events (for example, the first sit-ins and boycotts, which occurred in 1960). Any number of other factors not controlled for, or which could not be assessed without at least a pretest on the white and black comparison groups, might also have contributed to the change.

The other study to approximate a quasi-experimental design was published in 1972 by David Armor. ${ }^{24}$ At first glance, Armor's basic design appears satisfactory. The study incorporates a pretest and a posttest for the black students who were bused to the Boston suburbs as part of the METCO program with a pretest and a posttest for those who stayed in the Boston schools.

Armor reported an increase in endorsement of "separatist ideology," which he and St. John ${ }^{25}$ regard as an increase in prejudice. However, as Pettigrew and his colleagues were quick to point out, ${ }^{26}$ Armor's comparison group consisted of the siblings of the METCO students; as many as 62 percent of these siblings attended desegregated schools in Boston. Hence, even if

22. Webster, The Influence of Interracial Conlact on Social Acceptance in a Newly Integrated School, 52 J. Educ. Psych. 292 (1961).

23. Id. at 296. See also N. ST. John, supra note 4, at 188.

24. Armor, The Evidence on Busing, 28 PuB. InTERest 90 (1972). The study focused on Boston's METCO, a voluntary program, in which approximately 1,500 black students of all age levels were bused across district lines to predominantly white suburban schools.

25. N. St. Joнn, supra note 4 , at 182

26. Pettigrew, Useem, Normand, \& Smith, Busing: A Review of "The Evidence," 30 PUB. INTEREST 88,89 (1973) [hereinafter cited as Pettigrew]. 
we consider "separatist ideology" as a measure of antiwhite prejudice and find the study to have yielded some evidence on the effects of the means by which black students get to school, it cannot be classed as a study of the effects of school desegregation when the design compares one group of desegregated students with another.

In summary, there are apparently no experimental or quasi-experimental studies with sufficient methodological rigor to shed any light on the effects of school desegregation on either student racial attitudes or behavior.

\section{Longitudinal Studies}

\section{Methodological Considerations}

When a research design involves tests or observations at two or more points in time but does not include the comparison group required for a true or quasi experiment, it is called a longitudinal study. Sometimes the same school or classroom is observed two or more times-for example, first graders in a certain classroom are interviewed in 1972 and a different set of firstgrade students in the same classroom are interviewed in $1976 .{ }^{27}$ In other studies, the same students are tested or observed two or more times-for example, fourth graders tested in 1965 are tested again in 1966 as fifth graders and again in 1967 as sixth-grade students. ${ }^{28}$ These studies have four significant methodological weaknesses that limit the way they can be interpreted. Three of these-external historical trends, maturation of the students, and effects of repeating the test in subsequent years-were discussed above in connection with experimental and quasi-experimental designs. The fourth weakness is that independent changes in the social or racial composition of the school or class may give the impression of being changes produced by desegregation. For example, the more prejudiced students may leave the desegregated school after the pretest or the first posttest, so that those remaining appear on the average to have become less prejudiced. This effect is especially a problem with long-term longitudinal studies. Since longitudinal studies do not have a control group to guard against these misinterpretations, their usefulness is limited to certain cases-for example, when the object of study is interracial behavior within the desegregated school. Since there cannot be any interracial behavior in a segregated school, a mathematical estimate of what would occur under certain assumed conditions can be used for comparisons. ${ }^{29}$

27. Morland, Race Attitudes and Race in Public Schools: A Case Study of Lynchburg, Virginia (1976) (unpublished paper) (ERIC Document No. 131 166).

28. School Desegregation: A Long-Term Study 53 (H. Gerard \& N. Miller eds. 1975) [hereinafter cited as School Desegregation: A Long-Term Study].

29. See p. 11 infra. Interrupted time series can be used as a data analysis technique in longitudinal studies, as in the case of the white flight studies. See Rossell, School Desegregation and Commu- 
Because of these weaknesses, longitudinal studies of interracial attitudes are not discussed in this article. ${ }^{30}$ Instead, I shall concentrate on two types of longitudinal studies of behavior-those involving direct observation and those using sociometry (the measurement of social phenomena by questions that require individuals to choose other individuals within a given social setting).

\section{Observational Studies}

Silverman and Shaw undertook an observational study in Gainesville, Florida, ${ }^{31}$ in which two graduate students were posted at each of the two principal "places where large flows of students moved from their last classes off the grounds" at two junior high schools and at the tenth-grade (morning) and eleventh- and twelfth-grade (afternoon) sessions of the senior high school. ${ }^{32}$ One observer at each point used a pocket counter to record the total number of students interacting, that is, "talking or obviously walking with others."33 The other observer at each point counted the total number of students interacting in racially mixed groups. The second observer also counted how many interracially interacting students were in same-sex groups and how many were in cross-sex groups. These observations were made for identical time intervals during the third, eighth, and thirteenth weeks of the first semester after the schools had gone from token desegregation to full desegregation, which resulted in schools ranging from 30 to 50 percent black.

For the three younger student groups (the two junior highs and the tenthgrade session of the senior high), Silverman and Shaw found that the number of interracial interactions as a percentage of the total increased from the beginning of the term to the middle and then decreased somewhat from the middle to the end, though the final percentages were still higher than those at the beginning of the term. Among the older students, the three percentages were virtually identical over the time period. However, even the trends for the younger students were not statistically significant, so that the authors qualify their findings as the "merest suggestion" of a change across the ten-week interval. $^{\mathbf{3 4}}$

nity Social Change, 42 Law \& Contemp. Prob., Summer 1978, at 133. However, the technique has not been used in the school desegregation research on race relations. This, most likely, is because there is not a sufficient amount of data available for the predesegregation series of the interrupted time series. For an example of how this technique was used to measure academic achievement before and after desegregation in Goldsboro, North Carolina, see R. Mayer, C. King, A. Borders-Patterson, \& J. McCullough, The Impact of School Desegregation in a Southern CITY (1974).

30. For some examples, see Morland, supra note 27; Green \& Gerard, School Desegregation and Ethnic Attitudes, in Integrating the Organization 291 (H. Fromkin \& J. Sherwood eds. 1974); Silverman \& Shaw, Effects of Sudden Mass School Desegregation on Interracial Interaction and Attitudes in One Southern City, 29 J. Soc. Issues, Autumn 1973, at 133.

31. Silverman \& Shaw, supra note 30.

32. Id. at 134 .

33. Id

34. Id. at 136 . 
These findings can be interpreted in several ways. There were some interracial interactions, though not many ${ }^{35}$ - with a nonsignificant tendency for them to increase and then drop off somewhat over a brief period during the first semester of desegregation. Silverman and Shaw compared the observed percentages to a figure of 50 percent, which is about what would be expected if race were not a factor in the interaction patterns. Since the observed percentages fell far short of this figure, which was derived from the assumption that student behavior would change from almost total segregation to true integration (where race would be irrelevant) in ten to thirteen weeks, Silverman and Shaw reached a pessimistic conclusion regarding the effects of this instance of school desegregation upon interracial behavior.

However, it would be more appropriate to compare the percentage of observed interracial interactions to zero, since black and white students who had remained in segregated schools would not have been able to interact at all. The data are not available to test for a difference from zero in the published version of the Silverman and Shaw study. However, based upon the data they do report, it is clear that in the eighth and thirteenth weeks at the two junior highs, interracial interactions were well above zero.

The only other methodologically sound longitudinal study that observed interracial behavior directly was done by Schofield and Sagar. ${ }^{36}$ These researchers studied the cafeteria seating patterns of seventh and eighth graders in a 48 percent black, 52 percent white "magnet" school in a Northern city. ${ }^{37}$ The students and the faculty of both races were volunteers for the program. The school administrators, teachers, and staff endorsed and supported positive interracial relations and provided an extensive program of activities specifically designed to help students meet and interact with one another. At the same time, the racial compositions of the seventh and eighth grades of the school differed considerably. In the seventh grade there was no academic tracking system, and the racial proportions in each class were roughly equivalent to those in the grade as a whole. In the eighth grade, however, an accelerated academic track was 80 percent white. Students in this track attended almost all classes together, encountering nonaccelerated students only in gym classes and the lunchroom (where the study was conducted). A "heavy proportion" of those eighth graders not in the accelerated track were blacks. ${ }^{38}$

During the first year of the school's operation (1975-76), trained observers

35. The percentages ranged from less than $1 \%$ to $10.3 \%$. Id.

36. Schofield \& Sagar, Peer Interaction Patterns in an Integrated Middle School, 40 Sociometry $130(1977)$.

37. Sixth-grade students also attended the school. However, their cafeteria seats were assigned by school authorities, so they were not free to choose their lunch partners as the seventh and eighth graders could, Id. at 133 .

38. Id. 
noted the race and gender of both face-to-face and side-by-side cafeteria seating patterns for one day a week over a seventeen-week period-from February, when the school reopened after a citywide teachers' strike, to late June, when the school closed for the summer. ${ }^{39}$ The extent to which seating patterns corresponded to race and gender was measured using an index developed by Campbell, Kruskal, and Wallace in their study of college seating patterns. ${ }^{40}$ Schofield and Sagar found that for both side-by-side and face-to-face seating, there was more same-race seating than would have been expected if seating were random. This was true for both grades and both sexes. ${ }^{41}$ However, sex was generally a stronger predictor of seating aggregation than race was. More importantly, from February to June, both face-to-face and side-byside seating patterns shifted significantly toward racial randomness (that is, race became less of a factor in seating patterns) in the nontracked seventh grade. On the other hand, in the tracked and de facto racially imbalanced eighth grade, there was no significant shift among side-by-side seating patterns. And face-to-face seating for that grade shifted toward greater racial aggregation-that is, race became more of a factor.

This study by Schofield and Sagar is very important because it is the most methodologically rigorous and sophisticated study in print. As the authors point out, interpretation of its findings will depend on the reader's values and outlook on life. Segregationists and pessimistic integrationists can emphasize that all seating patterns revealed significantly more within-race seating (segregation) than would have been expected by chance. Optimistic integrationists can emphasize that there was a shift in the seventh grade toward less segregated seating over a relatively brief period of time, while the rigidly tracked eighth graders shifted toward more segregated seating. And, of course, even in the eighth grade there was more interracial seating than there would have been in racially separate schools.

\section{Sociometric Studies}

Research on interracial walking or seating patterns is direct observation of behavior. Walking and sitting together are minimal preconditions for more

39. The school had been open from September to late November when it closed for the strike; Schofield and Sagar started their study at that time. However, they noted little interracial interaction during the prestrike period, and their sampling method made for unstable estimates of the seating patterns. After the strike, they changed their sampling methods in order to get a more accurate estimate of the seating patterns. For an unpublished report of the methods and findings from the prestrike period, see Schofield \& Sagar. Interracial Behavior in a "Magnet" School (1977) (paper delivered at American Psychological Association Convention, San Francisco, California, 1977) (ERIC Document No, 147432 ).

40. Campbell, Kruskal, \& Wallace, Seating Aggregation as an Index of Attitude, 29 Sociometry 1 (1966).

41. The average racial seating aggregation for males was significantly less than that for females. Schofield \& Sagar, supra note 36, at 134. 
socially and psychologically meaningful interactions. However, if attitudes and other behaviors are to be affected more permanently, more than physical proximity is required. Social scientists have attempted to move beyond simply counting and noting the color of the noses in social interactions by using a technique known as sociometry or sociometric choice analysis, pioneered in the 1930 s by Moreno. ${ }^{42}$ The subjects of study are asked to indicate whom in the class or work group they want for a friend, a work partner, a teammate, and so on. In some studies, the subjects are also asked for a series of ranked choices, or for the names of those whom they do not want for a partner. Care should be taken in interpreting these studies in the context of desegregation. As Schofield and Sagar point out, ${ }^{43}$ the validation studies that link the selfreported behavior (friendship with the person named, and so forth) to actual behavior have all been done using only white students, and these questions may have a different meaning for minority students. ${ }^{44}$ In addition, we should expect less change over short time periods for sociometric choices than for such behaviors as sitting together, since it takes more time to learn whom you would like to have as a friend or as a work partner. Hence, early in a desegregation experience, one could expect that the students would draw heavily upon those whom they knew before.

There are two sociometric longitudinal studies of school desegregation of enough methodological rigor to make them worth examining. ${ }^{45}$ The first of these was conducted by Marvin Shaw in the Gainesville, Florida, schools. ${ }^{46} \mathrm{He}$

42. J. Moreno, Who Shall Survive? (1934). See also Bonney \& Powell, Differences in Social Behavior Between Sociometrically High and Sociometrically Low Children, $46 \mathrm{~J}$. EdUC. ReSEARCH 481 (1953); Davis \& Warnath, Reliability, Validity, and Stability of a Sociometric Rating Scale, 45 J. Soc. Psych. 111 (1957).

43. Schofield \& Sagar, supra note 36, at 131.

44. Teplin, Preference Versus Prejudice: A Multi-Method Analysis of Children's Discrepant Racial Choices, 58 Soc. ScI. Q. 390 (1977).

45. The ERIC search unearthed an unpublished study that deals with sociometric choices. J. Howell, Factors Contributing to a Successful Instance of Elementary School Desegregation (paper delivered to the American Educational Research Association, San Francisco, California, April, 1976) (ERIC Document No. 120 316). This study of desegregation in Springfield, Massachusetts, found that third through fifth grade classrooms composed entirely of students who had had a previous desegregation experience had, on the average, a significantly higher proportion of otherrace choices (blacks choosing whites and whites choosing blacks) than did classrooms composed of students without prior desegregation experience. The study also indicated a nonsignificant tendency for the proportion of other-race choices in both classrooms to increase over the first year of complete desegregation. Howell's study is not reported in any detail here because it is unpublished and because it does not include sufficient information on method or results to enable the critical reader to evaluate its worth. One other problem with the study is that the unit of analysis is the classroom and not the individual student. To infer individual level attitudes and behaviors from a higher unit of aggregation, such as the classroom, is called the "ecological fallacy" in the methodological literature. For a discussion of the ecological fallacy, see Shively, "Ecological" Inference: The Use of Aggregate Data to Study Individuals, 63 Am. Political Sci. Rev. 1183 (1969); R. Ashmore \& J. McConahay, Psychology and America's Urban Dilemmas $20-21$ (1975).

46. Shaw, Changes in Sociometric Choices Following Forced Integration of an Elementary School, $29 \mathrm{~J}$. Soc. Issues, Autumn 1973, at 143 [hereinafter cited as Shaw]. 
distributed sociometric choice questionnaires to a sample of fourth, fifth, and sixth graders in February, 1970, just after the elementary schools were desegregated, and again to those students in June of 1970. In February, 1971, he retested the same students (now in the fifth and sixth grades), who had been fourth and fifth graders in February, 1970. The desegregation had been court ordered, and the students had no choice of what school they attended. Instruction in the school Shaw studied was by team teaching, in which teams of three to six teachers were responsible for 90 to 130 students in classrooms opening into a central quadrangle. The students moved freely about the classrooms that opened into their quad. The faculty of the teams in each quad had been desegregated even before student desegregation was ordered. On each visit of the research team, the students were asked to choose three persons in the quad with whom they most preferred to be, and three with whom they least preferred to be.

The data were reported for only the first choices for both most and least preferred quadmates. With minor exceptions, both blacks and whites preferred students of the other race significantly less than would have been expected if race had not been a factor in their choice. Blacks also rejected whites, or said that they least preferred to be with them, significantly less than would be expected by chance. This tendency became even stronger over time. That is, blacks became more and more likely to limit their rejections to other blacks. Whites initially rejected blacks significantly less than would have happened by chance, but this shifted over time to a level of chance rejection (whites as likely to reject a black as to reject a white student).

On the basis of these findings, Shaw concluded:

These data provide little support for the hypothesis that equal status association will lead to greater acceptance of members of another race. On the contrary, it appears that association with members of the other race, at least in the school studies, leads to less acceptance of members of the other race. ${ }^{47}$

However, if Shaw had analyzed the data on the basis of a comparison with zero preferences or rejections for members of the other race, which would be expected in a segregated classroom, instead of with randomness, his results would have shown statistically significant preferences for students of the other race over what would have been expected under segregation. In fact, Shaw was aware that a comparison with zero would have yielded a more favorable evaluation than the one quoted above. In his concluding statement, he noted that the sociometric choices were certainly not equal to zero and instead indicated considerable interracial activity. His final conclusion, then, was that "equal status association may not eliminate the cleavage between races, but it

47. Id. at 151 . 
may eliminate much of the hostility between races that has been fostered by unequal status nonassociation." 48

A second sociometric study spanned the longest time period of any of the longitudinal studies and included black, white, and Mexican American students. $^{49}$ In 1966, when the Riverside, California, school board decided to desegregate all of its elementary and secondary schools, Gerard and Miller organized a study of the effects of desegregation upon academic performance, personality adjustment, and social contact in these schools. ${ }^{50}$ The researchers were able to obtain sociometric choice data in the spring of 1966 , before the major part of the desegregation plan was implemented, and to obtain the same sociometric data for at least four and, in some cases, five and six years after desegregation. Though there was no appropriate control group that remained segregated over this period, ${ }^{51}$ the study is still the most extensive long-term longitudinal study that has been done.

In this study, students were asked to pick the three classmates they would want for a friend, three they would want as schoolwork partners, and three they would want as members of a ball team. ${ }^{52}$ Using the standard methods of sociometry to describe and analyze social stratification, the researchers concluded that older black students (fourth through sixth graders) and all Anglo students generally maintained their relative social status after desegregation. In contrast, Mexican Americans generally lost status in the classroom, as did younger blacks (kindergarten through third graders), especially young black girls. ${ }^{53}$ These findings, however, did not apply to the choice of play partners. While Anglos were the most popular play partners in kindergarten through third grade, minority children (especially black boys) were the most popular partners in the fourth through sixth grades. Since students were asked to pick three members for a "ball team," the popularity of black males in the higher grades may reflect either the real athletic prowess of these youngsters or the acquisition by others of the stereotype that these students would be the best athletes, rather than friendship-related preferences. The researchers used statistical controls to show that the higher classroom status of Anglo over Mexican American and black students remained even after eliminating any boosts in status the Anglos may have received because of the socioeconomic status of their parents and their higher academic performance.

48. Id. at 156 .

49. Gerard, Jackson. \& Conolley, Social Contact in the Desegregated Classroom. in $\mathrm{SCHOOL}_{\mathrm{CH}}$ Desegregation: A Long-Term Study, supra note 28, at 211.

50. School Desegregation: A Long-Term Study, supra note 28. The Riverside study also produced a report on attitudes by Green and Gerard. Green \& Gerard, supra note 30.

51. If there had been an appropriate control group or a set of control groups, then the study would have had an experimental or quasi-experimental design. See notes 15-21, supra, and accompanying text; Campbell \& Stanley, supra note 15.

52. Gerard, Jackson. \& Conolley, supra note 49, at 214.

53. Id. at 217 . 
The investigators reported two findings that they regarded as encouraging. First, peer acceptance had no effect on the academic performance of the minority (black and Mexican American) students who were doing poorly before desegregation; the minority students who were doing well academically only showed a decrement in performance after desegregation if they were not well accepted by their Anglo peers. ${ }^{54}$ In addition, the sociometric choices of minorities by Anglos were found to be related to the degree to which teachers were biased in their evaluations of minority students. That is, there were significantly more minority sociometric choices by Anglo students in classrooms where teachers were less biased than in classrooms where teachers were more biased. ${ }^{55}$ The authors of the Riverside School study concluded:

The unprecedented amount of data we have examined points unmistakably to the conclusion that, with the exception of playground interaction, little or no real integration occurred during the relatively long-term contact situation represented by Riverside's desegregation program. If anything we found some evidence that ethnic cleavage became somewhat more pronounced over time. ${ }^{56}$

These conclusions are consistent with the data as viewed and analyzed by Gerard and his colleagues. However, looking at status stratification in the classroom (no matter how orthodox or standard that approach might be in the sociometric literature) might have resulted in a somewhat distorted picture in the absence of an appropriate control or comparison group. Because this study is so important, and because it is widely cited by those who question the value of desegregation, ${ }^{57}$ it is worth examining in some detail.

First, Gerard and Miller's study measured social status as a form of popularity. The group getting the most friendship choices and work partner choices-the group that was on the average most popular-was said to have the most status. What this means is that Gerard and Miller found that the Anglos, who were the most populous group, were also the most popular.

Second, Anglo popularity reflected not only their numerical superiority in

54. Id. at 234. This is only faintly encouraging, of course. It means that the general decline in academic performance reported by Gerard and Miller did not occur among students who had been doing well before desegregation and who were then liked by their Anglo peers after desegregation. On the other hand, Lewis and St. John report a more positive effect for white peer acceptance upon the academic performance of black students. Using path analysis, they found that sixth-grade academic achievement of blacks in majority white classrooms was positively related to popularity with whites as measured by sociometric friendship choices. See Lewis \& St. John, supra note 1.

55. Gerard, Jackson, \& Conolley, supra note 49, at 236. This is more encouraging than some of the other results, because the bias of the teachers is potentially more readily altered at the system level by re-education, firing, or reassignment than are other factors that might affect the attitudes and behavior of Anglo students.

56. Id. at 237 .

57. See, e.g., Coleman, Can we integrate our public schools without busing?, Chicago Tribune. Sept. 17. 1978, $\$ 2$ (Perspective), at 1,5 . 
the school but their status in American society at large. Although the authors tried to control for this, there were problems with the controls they used. The principal problem was that regardless of whether the control was satisfactory from a technical perspective (which it was not), ${ }^{58}$ social status is multidimensional in our society. While the Riverside researchers controlled for the achieved status represented by occupation, ${ }^{59}$ they did not control for the ascribed status of ethnicity. It is common knowledge in our culture that Anglos generally have higher status than Mexican Americans and blacks or other minorities of color ${ }^{60}$ Hence, Gerard and Miller did not control for the dimension of status most relevant to their analysis, nor could they or anyone else have introduced that type of control mathematically.

The major finding of Gerard and Miller, then, was that the social status system of the elementary schools of Riverside, California, reflected the system of the larger society: the most popular students were drawn from the numerically and socially dominant Anglos. To expect desegregation of the schools in one city to distort greatly this reflection of the larger society is a high standard to use in evaluating the effects of the desegregation program. A more realistic question to ask in evaluating desegregation would be: Does the program modify in some way the social stratification system that would have been in effect without desegregation? In other words, it may be that the Riverside researchers found a nearly perfect reflection of social stratification of America in general and Riverside in particular. After desegregation, AngloAmericans might still be the most popular group or the one with the most status, but this stratification might be less pervasive than in the larger society. Without a control group or other appropriate comparison data, the question cannot be answered except in the all-or-nothing dichotomy imposed on it by Gerard, Miller, and their fellow researchers. ${ }^{61}$

58. For a technical discussion of the problem of "control" when at least two of the "control" variables are highly correlated or "collinear," see Blalock, Correlated Independent Variables: The Problem of Multicollinearity, 42 Soc. Forces 233 (1963); Meehl, Nuisance Variables and the Ex Post Facto Design, in 4 Minnesota Studies in the Philosophy of Science 373 (M. Radner \& S. Winokur eds. 1970). For less technical discussions, see D. Campbell \& J. Stanley, supra note 15 ; E. Tufte, Data Analysis for Politics and Policy 148-55 (1974).

59. They used the Duncan Index for Occupations. See Duncan, A Socioeconomic Index for All Occupations, in Occupations and Social Status 109 (A. Reiss ed. 1961).

60. The classic analysis of the class and status situation of black Americans is J. Dollard, Caste and Class in a Southern Town (1937). A more recent discussion and analysis is in Cohen, supra note 3. See also Cohen, Lockheed, \& Lohman, The Center for Interracial Cooperation: $A$ Field Experiment, 49 Soc. Educ. 47 (1976).

61. Gathering those data would have required more resources than were available to Gerard and Miller, especially since social stratification by race in the schools was not their primary interest. With more resources they might have gathered sociometric data in the larger community or in the junior and senior high schools, which were desegregated before the elementary schools. Over time, the junior and senior high schools would eventually change from schools in which the students were having their first interracial experiences to schools that were part of a continuing desegregation experience. Hence, they could have used some analytical technique to approximate an interrupted time series analysis. See D. Camprell \& J. Stanley, supra note 15. 
Though they did not rely heavily upon it in their analysis, Gerard and Miller did report data on the preferences Anglos had for associating with minority students, a measure that is not as dependent on a control group for interpretation as is social stratification. Choices by Anglos to associate with minorities are interesting in their own right but also interesting in that they may reflect attitudes as well as behavior. As noted above, in a segregated situation, the number of Mexican American or black classmates chosen for friends or work partners by Anglos would be zero. Hence, if these out-group choices differ from zero and increase over time, this finding could indicate a lessening of antiblack or anti-Mexican American prejudice even though the ideal situation, in which race is not a factor in choosing friends or co-workers, was not attained during the period of the study.

The data show that the likelihood of an Anglo choosing minority students as friends and schoolwork partners increased somewhat over the years after desegregation, the only exception being the choices of Mexican Americans as schoolwork partners. The data do not permit us to test the significance of these postdesegregation changes, ${ }^{62}$ but in each instance it is clear that the average rate of interracial interaction in Riverside was greater than would have been the case if there had been no desegregation.

\section{Summary of Findings from Longitudinal Studies}

There is some consistency among the findings of the four most methodologically sound longitudinal studies of those I reviewed. The picture that emerges is that though desegregation does produce friendly interracial interactions and sociometric choices, we have not reached the state of true integration where friendships and associations are on a basis that is irrelevant to race. Given the stormy history of American race relations, ${ }^{63}$ we should not expect this "color blindness" to happen very quickly in the schools. Nor is this state of true integration likely to be reached in the schools or the larger society for years to come. On the other hand, the studies show that while race is still a potent factor in determining social relations in the schools, it is not as strong as gender in the instances where the two were compared. ${ }^{64}$

The Schofield and Sagar study of seating patterns and the Gerard and Miller study of sociometric choices illustrate what may be one of the most crucial factors in producing friendly interactions: what happens inside the classroom in the desegregated school. In the magnet school studied by Schofield and Sagar, all of the students were voluntarily desegregated. Nevertheless, those who were assigned to classes that were overwhelmingly single race be-

62. Though the means are given or can be calculated from other published data, the standard deviations and the covariances across time are not reported.

63. McConahay \& Hough, supra note 14, at 39-44; D. Sears \& J. McConahay, The Politics OF ViOLENCE 3, 196-209 (1973).

64. See, e.g., note 41 supra and accompanying text; note 80 supra and accompanying text. 
came more racially segregated in their seating over the period of the study than did those in more racially balanced classrooms. In Riverside, where the students did not have a choice of schools to attend, Gerard and Miller found that white students with racially or ethnically biased teachers made fewer minority sociometric choices than the students with less biased teachers. Hence, with both voluntary and mandatory motivations for attending a desegregated school, the outcome was affected by classroom factors. It appears, then, that while desegregating schools, even if ordered by governmental authorities, may be a necessary condition for increasing friendly interracial behavior, it certainly is not a sufficient condition. Future studies will have to consider not only desegregation at the school level but also what happens once the children arrive at the desegregated schools.

\section{Cross-Sectional (Correlational) Studies}

\section{Methodological Considerations}

The weakest studies, in terms of confidence in the interpretation of a given result, are the cross-sectional or correlational studies, so called because the data are gathered at one point in time across a variety of school environments. The racial compositions of the schools or classrooms are then correlated with racial attitudes or racially relevant behaviors such as sociometric choices. Among the published literature, there are many more of these studies than studies with a time dimension, probably because cross-sectional or correlational studies are the quickest and cheapest types of empirical research to do. The two major threats to the validity of these studies are misspecification of the model and identification. ${ }^{65}$ Both of these problems have to do with isolating what is really "causing" the effect when two variables or factors are found to be associated in a systematic fashion (correlated in a mathematical or statistical sense).

A properly specified model is necessary, for when two variables are positively or negatively correlated-when an increase in one is associated with an increase or decrease in the other-some third factor may be causing the change in both variables. For example, a positive correlation at one point in time between the percentage of blacks in a school and the racism scores of whites in that school might be the result of school authorities (or housing patterns) mixing white students from families with low incomes and little education with black students. ${ }^{66}$ Hence, the association between attending

65. E. TUfte, supra note 58; R. BeAls, Statistics for Economics 371-93 (1972); Erlanger \& Winsborough, The Subculture of Violence Thesis: An Example of a Simultaneous Equation Model in Sociology, 5 Soc. Methods \& Research 231 (1976).

66. The correlation between social class and ethnic and racial prejudice is well established in the literature. See Ashmore, Prejudice: Causes and Cures, in Social Psychology 243-339 (B. Col- 
desegregated schools and having high racism scores may be caused by low income or education in the families of the whites in such a study. In order to rule out these third, fourth, fifth, and other variables as causes for both the desegregation and the racism, the social scientist must consider all other potential variables and then measure these and enter them in a multiple regression equation or develop some other multivariate control procedure. This control effort is called specifying an appropriate model. ${ }^{67}$ Model specification depends on good theory-to know what to control-and on substantial financial resources-to measure all control variables adequately. Unfortunately, desegregation research has very inadequate theory ${ }^{68}$ and limited financial support. In addition, there may be some research settings in which it is impossible to control for all potential causes of spurious association because the potential causes are themselves so highly related that they cannot be teased apart mathematically. ${ }^{69}$

The second major problem posed by cross-sectional or correlational research on desegregation and racial attitudes and behavior is identification, or ambiguity in the direction of causation. The problem is to determine which variable is the cause and which is the effect, or whether the two are causing one another simultaneously and reciprocally. For example, even with a properly specified model, how can one know if a negative correlation between desegregation and white racism in students found in a given study results from desegregation reducing prejudice, or from low prejudice whites choosing to be desegregated, or from both tendencies reinforcing each other? There are some techniques for estimating the likelihood of the direction of causation, ${ }^{70}$ but dealing with this problem takes strong a priori theory, adequate research funding, and methodological skills that most researchers in this field do not have. Furthermore, without a true time dimension (as in experimental, quasi-experimental, and longitudinal designs), the problem of the direction of causation cannot fully be solved. ${ }^{71}$

In the studies summarized here, I have given the greatest weight to those making some attempt at model specification. None of the studies dealt with the problem of causal direction ambiguity, though some of the authors were aware of it and tried to deal with it by including previous measures for support (grade point average in earlier grades, for example).

lins ed. 1970); H. Ehrlich, The Social Psychology of Prejudice 65-79 (1973); Harding, Proshansky, Kutner, \& Chein, Prejudice and Ethnic Relations, in 5 Handbook of Social PsycholOGY 1, 56-60 (2d ed. G. Lindzey \& E. Aronson 1969).

67. E. TufTE, supra note 58; R. BEALS, supra note 65 , at 301-20.

68. Cohen, supra note 3 , at 293.

69. In the literature this is known as the problem of "multicollinearity." See note 58 supra.

70. The most popular are cross-lagged correlation, D. Campbell \& J. STanley, supra note 15, and simultaneous equation models, Erlanger \& Winsborough, supra note 65.

71. For a formal proof of this proposition, see Simon \& Rescher, Cause and Counterfactual, 33 Philosophy SCI. 323 (1966). 
Correlational studies of school desegregation, like all correlational studies, are plagued by these general problems. They are further limited in their potential for assessing the effects of school desegregation because many researchers have failed to include segregated schools or classrooms in their designs. The existing studies have compared schools that varied in their racial composition from 10 or 15 percent black to 10 or 15 percent white. Thus, we can compare the factors associated with variations in racial composition in already desegregated schools, but we cannot examine what correlates with desegregation itself.

Nevertheless, correlational studies, supplemented by the findings from other types of research, can suggest the best racial mixes and the most effective practices in use in previously desegregated schools, and thus facilitate the implementation of desegregation policy. ${ }^{72}$

\section{The Studies}

As was the case with longitudinal studies, correlational studies of racially relevant behavior and sociometric choices within the schools present the least difficulty for interpretation, while studies of interracial attitudes present the most. Hence, this review will concentrate upon the former. ${ }^{73}$ A study by Lundberg and Dickson ${ }^{74}$ and one by Gottlieb and TenHouten ${ }^{75}$ have received

72. That I do not consider all correlational research worthless is best illustrated by the number of correlational studies in which I have been involved. See D. SEARS \& J. MCConahay, supra note 63; McConahay \& Hough, supra note 14.

73. My search of the literature disclosed the following published studies that are so weak methodologically as to be worthless for assessing the effects of desegregation. I mention them here because many of them have been cited by one or more of the previous reviewers. Crooks, The Effects of an Interracial Preschool Program upon Racial Preference, Knowledge of Racial Differences, and Racial Identification, 26 J. Soc. Issues, Autumn 1970, at 137; Dentler \& Elkins, Intergroup Attitudes, Academic Performance, and Racial Composition, in The URBAN R's 61 (R. Dentler, B. Mackler, \& M. Warshauer eds. 1967); Kaplan \& Matkom, Peer Status and Intellectual Functioning of Negro School Children, 4 Psycr. Schools 181 (1967); Patterson \& Smits, Reactions of Inner-City and Suburban Adolescents to Three Minority Groups, $80 \mathrm{~J}$. Psych. 127 (1972); Useem, White Students and Token Desegregation, 10 InTEgrated Educ., Sept.-Oct. 1972, at 46; Wade \& Wilson, Relatively Low Prejudice in a Racially Isolated Group, 28 Psychological ReP. 871 (1971). Special mention should be made of the study by Dentler and Elkins in this list, because it is cited so often in the literature, and also because it exemplifies most of the flaws of the other studies. Dentler and Elkins studied five white segregated schools $(0 \%$ to $1 \%$ black), five "naturally desegregated" schools ( $10 \%$ to $35 \%$ black), and one black "segregated" school (35\% white!). They could not identify the race of their individual respondents on a social-distance-from-blacks scale or on an "Anti-Negro Index," so they presented all school averages with blacks and whites lumped together. See note 45 supra. The results were not consistent across measures. The ( $35 \%$ white) black segregated school scored lowest on the black social distance scale and virtually tied for highest on "Anti-Negro Index"! Hence, the reader cannot be certain whether differences in racial composition across schools were due to white prejudice, black self-hatred, or black low selfesteem-or to various combinations that enhanced or cancelled (or both) these factors in individual schools.

74. Lundberg \& Dickson, Inter-Ethnic Relations in a High-School Population, 58 AM. J. Soc, 1 (1952).

75. Gottlieb \& TenHouten, Racial Composition and the Social Systems of Three High Schools, $27 \mathrm{~J}$. MARR. \& FAM. 204 (1965). 
a great deal of attention in the literature. However, since the Lundberg and Dickson study compared only two schools, and the Gottlieb and TenHouten study compared only three, differences between schools in types of teachers and administrators, history and tradition, physical plant, and a multitude of other tangible influences are hopelessly confounded with differences in racial composition. $^{76}$

As part of the longitudinal sociometric study of the Gainesville, Florida, schools discussed in the previous section of this article, ${ }^{77}$ a cross-sectional study of free period interracial interaction behavior after one year of desegregation was also conducted. Shaw found a significant correlation between interracial interaction and the percentage of blacks in the classrooms. As the percentage of black students (regardless of age or grade) declined (from 24 percent to about 15 percent), the proportion of interracial interactions relative to the total number of interactions increased.

St. John gathered sociometric data in the spring of 1961 that indicated the friendship choices received and given by 166 black students in the junior classes of two high schools in the same New England town. ${ }^{78}$ Both schools were about 16 percent black and 84 percent white. She identified which junior high school each student had attended and obtained estimates of the racial composition of these junior highs at the time her subjects attended them. This provided a rough estimate of the prior desegregation experience of her respondents. St. John found that the black students most often chosen as friends by their white classmates had attended junior high schools with a higher percentage of whites (31-99 percent white) than was present in the junior highs attended by the black students whom white classmates chose least often as friends (0-30 percent white). However, she did not find a relationship between racial representation and friendship choices given by blacks to whites. This study suggests that having more prior experience with whites made black high school students more popular with white classmates, but did not make them less or more prejudiced against whites than students with less experience in relating to whites. ${ }^{79}$

A study of elementary school students by St. John and Lewis found that among a sample of New England sixth graders in the spring of $1967,{ }^{80}$

76. For a study of attitudes rather than behavior in three schools, see Koslin, Amarel, \& Ames, A Distance Measure of Racial Attitudes in Primary Grade Children: An Exploratory Study, 6 Psych. Schools 382 (1969).

77. Shaw, supra note 46.

78. St. John, De Facto Segregation and Interracial Association in High School, 37 Soc. Educ. 326 (1964).

79. A retrospective study, which used a national sample of black adults, similarly found that blacks who attended desegregated schools were more successful in geting jobs but not more or less likely to be antiwhite in their attitudes than blacks who said they had gone to segregated schools. See R. Crain \& C. Weisman, Discrimination, Personality, and AChievement 154-78 (1972).

80. St. John \& Lewis, Race and the Social Structure of the Elementary Classroom, 48 Soc. Educ. 
sociometric popularity was more dependent on gender than on race. The researchers ran separate multiple regression equations for black boys, black girls, white boys, and white girls. The equations included measures relative to each classroom of the socioeconomic status and the grade point average of the students in grades one to five, as well as the percentage of whites in each classroom and the students' previous experience with students of the other race during grades one through five.

For boys, both black and white, the percentage of whites in the classroom was significantly correlated with out-group popularity (the popularity of blacks with whites and the popularity of whites with blacks). As the proportion of one group increased, the popularity of boys in that group with persons in the other group also increased. For black girls, the relationship was also significant-but in the opposite direction. As the proportion of blacks increased, the popularity of black girls with whites decreased. For white girls in the sixth-grade sample, there was no relationship between the percentage of whites in the class and their popularity with blacks.

For all four race and gender combinations, the only other significant correlate of popularity with the out-group was relative academic achievement in the past. ${ }^{81}$ High achievers were more popular with the out-group than were low achievers. For whites, previous academic achievement was a stronger correlate of popularity with blacks than was the racial composition of their classroom. For black girls, the two were of about equal strength in predicting popularity with whites. For black boys, racial composition was more important than academic achievement in predicting popularity with whites.

Patchen, Davidson, Hoffman, and Brown reported results generally consistent with these findings of St. John and Lewis. ${ }^{82}$ A sample of 1,800 black and 2,100 white high school students in Indianapolis responded to question-

346 (1975). Two other studies turned up in my search; I have not reviewed them here because they are as yet unpublished and because they study attitudes rather than behavior (or selfreported behavior). See C. Bullock, School Desegregation, Inter-Racial Contact, and Prejudice (1976) (final report to the National Institute of Education, Project No. 3-0182); W. Hawley. Teachers. Classrooms, and the Effects of School Desegregation on Effort in School: A "Second Generation" Study (Duke University Institute of Policy Sciences and Public Affairs Working Paper No. 4763, 1976). Bullock found that white eighth, tenth, and twelfth graders attending desegregated Georgia schools were more prejudiced than those attending segregated schools. In a multiple regression equation with a number of other factors, school desegregation was still negatively correlated with prejudice for his white respondents, but their parents' racial attitudes were even more strongly related to prejudice. For blacks, that relationship between parents' attitudes and prejudice was also found, but there was not a significant relationship between school desegregation and prejudice. Hawley found no relationship between classroom racial composition and prejudice for either race in his fifth-grade sample from North Carolina schools.

81. Thus St. John and Lewis did not replicate the findings of St. John, note 78 supra, that previous experience with whites was related to current level of popularity with whites. See St. John \& Lewis, supra note 80 , at 355 .

82. Patchen, Davidson, Hofmann, \& Brown, Determinants of Students' Interracial Behavior and Opinion Change, 50 Soc. Educ. 55 (1977). 
naires. On the basis of an elaborate set of multiple regression equations, the authors reported that two of their three measures of "opportunities for interracial contact" were significantly related to "positive interracial behaviors," while "opportunities for interracial contact" were not related to "negative interracial behaviors."

Except in that the findings of Patchen and his associates are consistent with those of St. John and Lewis for boys, I am not inclined to give them much weight. All of their measures are based on self-reported opportunities or behaviors. ${ }^{83}$ Thus, their measures represent what the respondents perceived or were willing to report on the questionnaires, rather than direct observations or data from independent sources regarding current opportunities and behaviors. Moreover, when the high school students reported that they had many (or few) occasions when they sat next to a person of another race in classes and that their interactions with other races were friendly (or hostile), was this because opportunity led to friendly behaviors or because friendly behaviors led to more opportunities? Thus, indirect measurement makes the direction of causation much harder to establish in this study than in the research of St. John and Lewis.

\section{Summary of Findings from Cross-Sectional Studies}

The cross-sectional studies reported represent the only ones with enough methodological rigor to make them worth discussing. ${ }^{84}$ They can be summarized in three ways. First, previous school experience with the other race did not consistently facilitate popularity with the out-group. St. John's black high school students apparently benefited (in terms of popularity with whites) from

83. Patchen, Davidson, Hofmann, and Brown measured "Opportunity for Interracial Contact" in three ways: (1) the number of classes reported by the student in which he or she allegedly sat "right next to one or more (other-race) students"; (2) the number of black teachers or other black staff persons that the student remembered and reported having worked with during his or her student career; and (3) the number of school activities (athletic teams, school paper, etc.) the student reported participating in. Positive interracial behaviors were measured in two ways: (1) "the average frequency with which student reported each of nine types of friendly interactions-e.g. did school work together" (emphasis added) and (2) the number of other-race friends the student reported. and belonging to an interracial informal group. Negative interracial behaviors were measured by (1) the average number of fights and arguments with "other-race" members reported by the student and (2) "the average frequency with which student reported avoiding other-race students in seven different situations (e.g. avoided sitting near such persons)." Id. at 58-59.

84. I have not discussed the Southern schools cross-sectional analysis that the National Opinion Research Center conducted concurrently with its ESAP experiment, supra note 21, for three reasons. First, it is not a published study but a report issued by NORC without being subjected to editorial review by an independent authority. Second-and much more important-the unit of analysis is the school rather than the individual student, the subject of this review. This presents the problem discussed previously, supra note 45: inferring attitudes and behaviors at the individual level from an aggregate analysis. Third, the problem of aggregate analysis, or ecological fallacy, is further exacerbated because the study reported and interpreted the findings on the basis of standardized regression coefficients (Betas) rather than using raw or unstandardized coefficients. which would have minimized the ecological errors. See Shively, supra note 45. 
grade school desegregation experiences in 1961, but St. John and Lewis did not re-encounter this trend among either black or white sixth graders in 1967. This may be because the skills learned from previous desegregation experiences are not required for popularity with other races until high school, or because the studies were done at different stages in the history of American race relations. ${ }^{85}$ This issue is interesting from both a theoretical and a practical standpoint; more research should be done on it.

Second, within schools that have been desegregated, the racial composition of the school or classroom is crucial in determining the level of interracial interactions and friendship choices. For boys in all of the studies, and for both boys and girls in several, as the proportion of the other race increased, the proportion of friendships with the other race increased. How encouraging this finding is for those wishing to promote interracial goodwill depends on how one interprets the increasing proportion of contacts with the other race. It is true that as the proportion of the other race increases, a student's opportunity for contact and friendships with the members of the other race also increases. However, since other-race and own-race proportions are usually reciprocally related, an increase in the proportion of the other race will result in a corresponding reduction in opportunities for friendships among students of one's own race at school. Hence, at some point in this balance, friendships and interactions with other races may increase in school but at the same time reduce the chance of these extending outside the school environment or reduce the likelihood of any favorable attitudinal change. Right now, of course, we do not know exactly where that point lies. Future research on racial composition should include both the proportion and the absolute number of same-race and other-race students in the school or classroom being studied, as well as measures of friendship patterns inside and outside of school. These studies should also measure attitudinal change and include a time dimension in the design.

Third, while these correlational studies may be helpful in deciding how best to implement desegregation policies, they tell us little about our main concern in this article: the effects of school desegregation. This is because segregated schools either were not included in the samples or because they were not analyzed separately from desegregated schools with a minority (sometimes even a sizeable minority) of blacks or whites.

\section{E. Summary of Findings From All Studies}

Reading this literature leaves one impressed with how little is known and how much additional research-especially experimental research-is needed. I begin this summary with such a statement not in obedience to standard aca-

85. Note 63 supra. 
demic ritual: the need for more research is truly impressive in this case. There is not one valid experiment, published or unpublished; the quasi experiments are too flawed in methodology to be of any value. While longitudinal studies can shed some light on interracial behavior when this behavior is assessed directly by observation or sociometric choice, only an experiment or a carefully designed quasi experiment can give us clear, epistemologically sound evidence of the effects of school desegregation itself on racial attitudes. ${ }^{86}$

Experimental and quasi-experimental research in the context of school desegregation is expensive and difficult, but not impossible to do. For example, if all of the schools (or classrooms) in a district cannot be desegregated at one time, or if the plan calls for phasing in desegregation over a year or more, a lottery or some other chance mechanism used in a highly visible manner might reduce complaints about unfairness and incidentally create the situation where the effects can be assessed rigorously with an experimental and a truly equivalent control group. In Louisville, for example, the children who would be bused were chosen by a quasi-random mechanism. ${ }^{87}$ Therefore, although we will not be able to assess the effects of desegregation there with any great rigor (because everyone was desegregated at the same time), we can study the effects of busing with considerable confidence. ${ }^{88}$

My second impression from this literature is that there was greater consistency in findings among the more methodologically rigorous studies of student behaviors than I had expected to find. It is clear that though students in desegregated schools (even after four or more years) have not reached the ideal state where race is not a factor in associational or friendship patterns, race is not as powerful a factor as gender; and interracial friendships are being formed, perhaps at an increasing rate. This could not happen in segregated schools.

Finally, the process of school desegregation is a complex set of events. What happens within the various desegregated schools may be as important in shaping interracial behavior as the initial fact of desegregating the schools—or even more important. The racial composition of the schools, the racial composition of the classrooms in the schools, and the racial attitudes of the teachers can either impede or facilitate friendly interaction and formation of friend-

86. I am not, of course, the first social scientist who has made a plea for experimental research in this area. See Gilbert \& Mosteller, The Urgent Need for Experimentation, in ON EQUaLITY of Educational Opportunity 371 (F. Mosteller \& D. Moynihan eds. 1972).

87. J. McConahay \& W. Hawley, Is it the Buses or the Blacks? Self-Interest Versus Symbolic Racism as Predictors of Opposition to Busing in Louisville (Duke University Institute of Policy Sciences and Public Affairs Working Paper No. 9772, 1977).

88. For an example of how a lottery was used for fairness and for rigor in an evaluation of the effects of an alternative high school upon racial attitudes and student achievement, see McConahay, Frey-McConahay, Trickett, Gruber, \& Hawley, Evaluation of High School in the Community, New Haven, Connecticut, in Alternative Education: A Source Book for Parents, Teachers, Students and Administrators 313 (M. Fantini ed. 1976). 
ships between races. If desegregated students are put in classrooms with few or no members of the other race, or if they are assigned to biased teachers, interracial friendships may not show any increase over what they would have been in a segregated school.

\section{III}

\section{Why We Should Expect Very Little From Desegregation}

In order to sell or discredit desegregation policy, old-line integrationists and old-line segregationists, as well as their contemporary counterparts in the busing debate, have exaggerated the changes in attitude and behavior we may expect from desegregation. Hence it is appropriate to pair the preceding analysis of the existing research on the effects of school desegregation with a discussion of what we might expect from school desegregation on the basis of social psychological theory and research set, for the most part, outside the school environment. This discussion may aid both researchers and policymakers as they design new studies and formulate new policy.

Americans, on the whole, have a great deal of faith in the beneficial effects of just getting people of different racial and ethnic groups together. ${ }^{89}$ Drake and Cayton ${ }^{90}$ have called this an "almost mystical faith." The formation of biracial committees was one of the instant responses of mayors to the urban rebellions of the $1960 \mathrm{~s} .^{91}$ Even so, much of the basic social psychological research suggests that we should not expect any positive change in attitudes or behavior from merely putting people together in the same building or room. In fact, we should more likely expect that a poorly planned and executed mixing of racial and ethnic groups would produce negative change. At least two fairly well established bodies of research would make these predictions: the research on interpersonal attraction and friendship formation (also mate selection), and the research on the socialization of intergroup attitudes.

\section{A. Interpersonal Attraction}

Three decades of laboratory and field research on what attracts people to one another and leads them to become friends suggests that it is much more likely to be birds of a feather who flock together than opposites who attract. ${ }^{92}$ We like people whom we perceive to like us; ${ }^{93}$ we like people whom we per-

89. Amir, supra note 5 .

90. S. Drake \& H. Cayton, Black Metropolis 281 (1945).

91. An instant response after scapegoating their political opponents, that is. See SEARS \& McConahay, supra note 63, at 147-57.

92. Bryne, Attitudes and Attraction, in 4 Advances in Experimental Social Psychology 35 (L. Berkowitz ed. 1969); T. Newcomb, The Acquaintance Process (1961); R. Winch, MateSelection (1958).

93. Backman \& Secord, The Effect of Perceived Liking on Interpersonal Attraction, 12 HUMAN REL. 379 (1959); Tagiuri, Person Perception, in 3 Handbook of Social Psycholocy 395, 425-30 (2d ed. G. Lindzey \& E. Aronson 1969). 
ceive to have similar social and demographic backgrounds; ${ }^{94}$ we like people with attitudes similar to our own. ${ }^{95}$ Other ethnic or racial groups are frequently assumed to have attitudes that differ from our own. ${ }^{96}$ As relationships develop, complimentarity of differences in certain emotional characteristics may deepen the relationship, ${ }^{97}$ but this happens only after the initial selection based on perceived similarity. As Amir ${ }^{98}$ asserted in 1975, ethnic and racial groups do indeed differ on surface characteristics, making it easy for an individual to expect that he or she will not like or be comfortable around people who are from groups different from his or her own.

\section{B. Socialization of Racial Attitudes}

There have been a number of recent reviews of the literature on the acquisition and subsequent development of intergroup attitudes. ${ }^{99}$ Though there is still some disagreement over the processes involved, ${ }^{100}$ there is a general consensus that these attitudes (1) are acquired very early, perhaps before age five or six, and certainly by age ten; (2) are acquired affectively and nonverbally before they are acquired cognitively; and (3) are relatively static throughout the individual's lifetime in the absence of major changes in the individual's social or demographic position. David Sears and I have called this "the psychology of enduring dispositions." ${ }^{01}$

The family plays the most important role in the early years of intergroup attitude formation, and children have been observed to behave differently toward persons of other races as early as age two or three. ${ }^{102}$ Furthermore, these attitudes are acquired even in the absence of direct contact with the other race. ${ }^{103}$ As the child matures, the schools and the larger culture, including the media, ${ }^{104}$ also exert an influence. Usually, however, due to de facto selective exposure, these only reinforce the direction of the family's

\footnotetext{
94. Bryne, supra note 92 ; R. WINCH, supra note 92.

95. T. NewcomB, supra note 92.

96. Rokeach, Smith, \& Evans, Two Kinds of Prejudice or One?, in The OPEn and Closed Mind 132, 134-35, 166 (M. Rokeach ed. 1960).

97. Levinger, Senn, \& Jorgensen, Progress Towards Permanence in Courtship, 33 SocromETRY 427, 441 (1970); R. WINCH, supra note 92.

98. Amir, supra note 5 , at 247.

99. Katz, The Acquisition of Racial Attitudes in Children, in Towaros The Elimination of RaCISM 125 (P. Katz ed. 1976); Proshansky. The Development of Intergroup Attitudes, in 2 ReviEW OF Child Development Research 311 (L. Hoffman \& M. Hoffman eds. 1966).

100. Katz, supra note 99 , at 148.

101. D. SEARS \& J. MCConahay, supra note 63 , at 41 .

102. Katz, supra note 99, at 130 ; J. Williams \& J. Morland, Race, Color, and the Young Child 62-133 (1976).

103. E. Horowitz, The Development of Attitude Toward the Negro (1936) (Archives of Psychology Serial No. 194); Horowitz \& Horowitz, Development of Social Attitudes in Children, 1 Sociometry 301 (1938); H. Erhlich, supra note 66.

104. Johnson, Sears, \& McConahay, Black Invisibility, the Press, and the Los Angeles Riot, $76 \mathrm{AM}$. J. Soc. 698 (1971); Greenberg \& Mazingo, Racial Issues in Mass Media Institutions, in Towards THE Elimination of Racism 309 (P. Katz ed. 1976).
} 
earlier socialization. ${ }^{105}$ There are examples of dramatic changes in stable attitudes, but these are usually preceded by dramatic changes in the individual's social and geographic location and are of interest primarily because they are so unusual. ${ }^{106}$ Hence, most people begin their journey through life with attitudes toward other racial and ethnic groups that are fixed early and remain stable to the end.

We should expect, then, that merely mixing persons of different races, social classes, and ethnic backgrounds will have very little effect on their basic attitudes. We should expect little (or even a negative) effect especially when it occurs under circumstances where the students perceive that they had little choice; where their parents, peers, and other reference groups in the larger community expect them to be negatively affected-or, at best, unaffected; and where little is done to encourage them to behave positively toward one another.

\section{IV}

\section{Why There Are Grounds For Some Optimism}

Though our expectations should be low with regard to positive effects from racial mixing (assuming again that racial harmony is our goal), we should not despair. Two developments in social science theory and research in recent years suggest that the outcome of school desegregation, when done properly, need not result only in small or negative change as the preceding synopsis would imply. One source of optimism is in basic attitude research; the other is in the more directly applicable field of research on prejudice reduction.

\section{A. The Relationship of Changes in Attitude to Changes in Behavior and Vice Versa}

For at least as far back in the history of social science as the turn-of-thecentury writings of William Graham Sumner, social scientists believed that attitudes led to behavior and that changing behavior through laws (or other external means) would be ineffective because the attitudes would be left untouched ${ }^{107}$ But in the 1950s, social psychologists began to demonstrate that causation could work the other way as well. ${ }^{108}$ That is, by changing behavior, attitudes could be changed. There is not yet a strong consensus in the field

105. Sears, The Paradox of De Facto Selective Exposure Without Preferences for Supportive Information, in Theories of Cognitive Consistency 777 (R. Abelson, E. Aronson, W. McGuire, T. Newcomb, M. Rosenberg, \& P. Tannebaum eds. 1968).

106. T. Newcomb, K. Koenig, R. Flacks, \& D. Warwick, Persistence and Change (1967).

107. W. G. Sumner, Folkways 55-58 (1906).

108. Janis \& King, The Influence of Role Playing on Opinion Change, $49 \mathrm{~J}$. A Bnormal \& Soc. Psych. 211 (1954); Festinger \& Carlsmith, Cognitive Consequences of Forced Compliance, $58 \mathrm{~J}$. ABNORMAL \& SOC. PSYCH. 203 (1959). 
over how or why this change occurs, ${ }^{109}$ and under certain circumstances the behavioral change can result in a boomerang or negative change in attitude. ${ }^{110}$ But it is now generally agreed that changing attitudes can change behavior and changing behavior can change attitudes. The significance of this for research on school desegregation and race relations is obvious. If in the desegregated school the students and teachers behave as though they respect and feel favorably toward one another, they can also come to feel that way after a while, regardless of their initial attitudes.

\section{B. The Contact Hypothesis}

Gordon Allport elaborated the initial theoretical and empirical basis for the conditions that would lead to a change in prejudicial attitudes, which is known as the contact hypothesis. ${ }^{111}$ As Amir $^{112}$ indicated, Allport discussed some thirty variables that can affect the success of intergroup contact in reducing prejudiced attitudes. In his clearest statement of the hypothesis, Allport reduced the model to the following form:

Prejudice (unless deeply rooted in the character structure of the individual) may be reduced by equal status contact between majority and minority groups in the pursuit of common goals. The effect is greatly enhanced if this contact is sanctioned by institutional supports (i.e., by law, custom or local atmosphere), and if it is of a sort that leads to the perception of common interests and common humanity between members of the two groups. ${ }^{113}$

Most discussion of the hypothesis focuses on the meaning of "equal status" and the necessity (or realistic possibility) of achieving "common goals." Because these are so central to the hypothesis, each deserves a brief elaboration.

\section{Equal Status}

In their critique of Armor's essay, The Evidence on Busing, ${ }^{114}$ Pettigrew, Useem, Normand, and Smith ${ }^{115}$. demonstrate that Armor, like many early researchers, incorrectly interpreted Allport's use of the term equal status to mean equal socioeconomic status. ${ }^{116}$ This would lead to the policy implication that middle-class blacks should be integrated with middle-class whites, and working-class blacks with working-class whites, and so forth. While

109. Bem, Self-Perception: An Alternative Interpretation of Cognitive Dissonance Phenomena, 74 Psych. Rev. 183 (1967); Collins \& Hoyt, Personal Responsibility-for-Consequences: An Integration and Extension of the "Forced Compliance" Literature, 8 J. Experimental. Soc. Psych. 558 (1972).

110. J. Brehm, A Theory of Psychological Reactance 95 (1966).

111. See generally G. Allport, supra note 6.

112. Amir, supra note 5, at 252.

113. Allport, supra note 6 , at 281.

114. Armor, supra note 24.

115. Pettigrew, supra note 26, at 91 .

116. Also see my comments on the use of SES controls in Gerard and Miller's study of Riverside, notes 59-61 supra, and accompanying text. 
desegregating in this fashion might ease some of the fears of middle- and upper-middle-class whites, it would also result in a few middle-class blacks mixed in with a great many middle-class whites, and a great many workingor lower-class blacks mixed in with a great many working- or lower-class whites. This situation would magnify existing class cleavages within each race as well as create interracial tensions among the newly desegregated workingand lower-class blacks and whites. Pettigrew and his colleagues argued that Allport really meant equal status in the contact situation-that is, one person would not be the supervisor, boss, leader, advisor, or teacher of the other. ${ }^{117}$ This would suggest that persons of different socioeconomic statuses in the larger community could be desegregated together as long as they were given equal status in the desegregated situation.

Unfortunately, this is not as easy to achieve in practice as in theory. As Cohen discovered, both black and white youngsters appear to attribute higher status and competence to the white child, even when the two have the same socioeconomic status and are in a situation where the white could not possibly have had any prior experience with the task or developed any special competence based on past experience with similar tasks. ${ }^{118}$ This implies that in the newly desegregated school, where there may be intense competition for grades and other academic rewards, equal status cannot be achieved by fiat, nor by simple good will on the part of staff and teachers. Cohen has been experimenting with a process she calls "expectation training," 119 which is designed to change the expectations of both blacks and whites that the white child will be more competent and of higher status in that context. This form of training is time consuming, expensive, and not easily adaptable for mass distribution. These are serious drawbacks, but doing nothing to create at least the expectation of equal status also is very costly, and will continue to be so.

\section{Common Goals}

Blacks, whites, and other humans share many long-range goals, but it is quite likely that in many situations their goals will not be so common. In experimental situations, where common or superordinate goals can be created for the groups in contact while interpersonal and intergroup competition can be minimized or eliminated, intergroup hostility and prejudice can be reduced. ${ }^{120}$ In the typical desegregated school, however, common or superordinate goals may not be as salient to the students of different races as competition among and within groups.

In 1975, Amir reported on some of his preliminary work to promote eth-

117. Pettigrew, supra note 26, at 92.

118. Cohen, supra note 3; Cohen, Lockheed, \& Lohman, supra note 60, at 48.

119. Cohen, Lockheed, \& Lohman, supra note 60 , at 48.

120. Ashmore, supra note 66; Amir, supra note 5. 
nic harmony between Israelis and Arabs by creating or emphasizing different goals that can be achieved only through mutual cooperation. If he is successful in the Middle East, this approach might be applied in desegregated American schools. Applying it here, however, may tax the ingenuity of school and community officials. This is an area that certainly deserves more field and laboratory research.

\section{Summary of Findings from Contact Hypothesis Research}

After an exhaustive review of the research on the contact hypothesis in settings such as schools, summer camps, work places, and the military, Amir tentatively proposed that the following conditions result in reduced prejudice (changed attitudes after contact). ${ }^{121}$ Most of these are neither necessary nor sufficient conditions; in a government-ordered desegregated situation, all of them might be required to produce any measurable effect.

1. Equal status within the contact situation.

2. Positive perceptions of the other group (regardless of status) resulting from activities during contact.

3. Contact with members of the out-group who are of higher socioeconomic status than the majority group members.

4. Contact under conditions requiring cooperation between ethnic groups (regardless of the nature of the goals).

5. "Intimate" rather than superficial contact.

6. The authorities of the social climate favor and promote the intergroup contact situation.

7. Contact in a situation that is pleasant or rewarding.

This is not a cheap package of conditions. Establishing them in a school desegregation situation will take a great deal of money, effort, and intelligence -and perhaps more interracial goodwill within the larger community than America has in stock right now. However, it will be costly not to do it. And that cost will mount with each year that action is deferred.

121. Amir, supra note 5, at 288. 